\title{
EDITORIAL: Terapia Psicológica, su ingreso al Web of Science y los nuevos desafios
}

Con mucho agrado presentamos a Uds. el número 3 de este año 2012. Por primera vez en su historia, Terapia Psicológica (TEPS) publica tres números al año en los meses de Abril, Julio y Diciembre. A partir de este año se constituye este nuevo desafío para la revista y la Sociedad Chilena de Psicología Clínica.

Durante el año 2010, Terapia Psicológica fue incorporada en la exigente base de datos de la WEB of Science (WOS), Thomson Scientific - Reuters, lo que la posiciona a nivel internacional entre las revistas científicas de mayor calidad e impacto.

Sin duda, integrar las selectivas y exigentes bases de datos que conforman el WOS resultaba una prioridad central para Terapia Psicológica, un antiguo anhelo para los diversos investigadores, asociaciones e instituciones que han colaborado.

Es particularmente relevante a nivel nacional el ingreso de Terapia Psicológica a la WOS pues la constituye como la primera revista de psicología chilena reconocida a ese nivel. Esperamos que nuestra inclusión sirva de plataforma y fomente el ingreso de otras publicaciones nacionales.

Esta distinción que ha recibido TEPS es el resultado del esfuerzo mancomunado de autores nacionales e internacionales, equipo y colaboradores de Terapia Psicológica, Directiva y la Sociedad Chilena de Psicología Clínica en su conjunto.

Debido a su ingreso al WOS durante 2011 Terapia Psicológica fue incluida en el Journal Citation Reports (JCR) recibiendo su primer índice de impacto (Factor de Impacto FI). Cabe señalar que para la evaluación eficiente de las revistas el JCR da a conocer el Factor de Impacto de 7.460 publicaciones, permitiendo comparar la importancia de una publicación en relación con otras del mismo campo y de la ciencia internacional.

A este respecto, Terapia Psicológica debutó en el JCR, obteniendo un factor de impacto de 0,609.

De acuerdo al JCR 2011 comparativamente hoy TEPS se sitúa dentro de las revistas incluidas en el WOS con JCR:

- número 2 entre 14 revistas de ciencias sociales chilenas.

- número 8 entre las 36 revistas de Chile.

- número 2 entre las revistas de Psicología Latinoamericana (incluyendo México y Brasil).

- entre las primeras 10 revistas de más de 20 revistas de Psicología en Iberoamérica.

Estos indicadores resultan esperanzadores y prometedores, considerando que es el primer índice de impacto reportado por el JCR para nuestra revista.

Asimismo, esto se suma a la valorización que ya había recibido Terapia Psicológica en otra de las más importantes bases de datos de revistas científicas como son las revistas Scopus. A partir de las revistas incluidas allí, TEPS recibió el SJR de 0,031 (Índice de impacto a partir de las revistas SCOPUS) ubicándola en el cuartil 3 (Q3), tanto en psicología clínica como también en el Q3 en la categoría de psiquiatría.

Dado lo anterior, consideramos que se avecinan nuevos retos a TEPS, como son entre otros, mantener y aumentar el índice de impacto, afianzar y aumentar este posicionamiento alcanzado y extender nuestra visibilidad entre la comunidad científica internacional. Asimismo, mejorar todos los procesos editoriales de la revista, principalmente en la revisión de la gran cantidad de artículos recibidos, lo que necesariamente implica aumentar la selectividad y criterios de calidad. TEPS debe además impulsar y desarrollar su relación con los investigadores acostumbrados a un alto nivel de rigurosidad y eficiencia y requiere por lo mismo considerable dedicación, minuciosidad y esfuerzo.

Hasta el momento los indicadores muestran que TEPS va en el camino correcto y ya se encuentra en el grupo más importante de las revistas científicas internacionales. Corresponde, entonces, mantener esta importante ubicación y seguir aumentando estos lugares y visibilidad internacional.

Pablo Vera-Villarroel

Director, Terapia Psicológica

Caterina Manzo, Jaime Silva y Walter Kühne Directores Asociados 


\section{EDITORIAL: Terapia Psicológica, joining the Web of Science and the new challenges}

It is with great pleasure that we present to you number 3 for 2012. For the first time in its history, Terapia Psicológica (TEPS) is publishing three numbers in one year: April, July and December. This represents a new challenge for the journal and for the Chilean Society of Clinical Psychology.

In 2010, Terapia Psicológica was incorporated into Thomson Reuters' demanding WEB of Science (WOS) database, thereby placing it among the world's scientific journals of greatest quality and impact.

Without a doubt, integrating into the selective and demanding databases that comprise the WOS was a central priority for Terapia Psicológica, a long-standing goal for the various researchers, associations and institutions that participated as authors or contributors.

The admission of Terapia Psicológica into the WOS is particularly relevant nationally as this makes it the first Chilean journal of psychology recognized at that level. We hope that our inclusion serves as a platform and promotes the admission of other national publications.

This distinction that TEPS has received is the result of the combined efforts by national and international authors, teams and collaborators of Terapia Psicológica, its Board and the Chilean Society of Clinical Psychology.

Due to its admission into the WOS in 2011, Terapia Psicológica was included in the Journal Citation Reports (JCR) and received its first impact factor (IF). It should be pointed out that for the efficient evaluation of journals, the JCR makes public the impact factor of 7,460 publications, so that the importance of a publication can be compared to others of the same field and of international science.

In this regard, Terapia Psicológica made its debut in the JCR, obtaining an impact factor of 0.609.

According to the JCR 2011 today TEPS is placed comparatively among the journals included in the WOS with JCR:

- number 2 of 14 Chilean social sciences journals.

- number 8 of 36 Chilean journals.

- number 2 of Latin American psychology journals (including Mexico and Brazil).

- among the top 10 of more than 20 psychology journals in Latin America.

These indicators are encouraging and promising, considering that this is the first impact factor reported by the JCR for our journal.

Moreover, this is added to the valuation that Terapia Psicológicahad already received in another of the most important scientific journal databases, SCImago Journal \& Country Rank (SJR). Of the journals included there, TEPS received a SJR of 0.031 (Impact Factor of SCOPUS journals), placing it in the third quartile (Q3) in clinical psychology and in Q3 in the psychiatry category.

We consider that the new challenges which lie ahead for TEPS include maintaining and increasing the impact factor, strengthening and increasing the positioningachieved,extending our visibility in the international scientific community and improving the journal's publishing processes, mainly in the review of the large quantity of articles received, which necessarily involves augmenting the selectivity and quality criteria. TEPS must also promote and develop its relations with researchers accustomed to a high level of rigor and efficiency and through them require considerable dedication, attention to detail and effort.

To date the indicators have shown that TEPS is on the right path and is already in the most important group of international scientific journals. We must therefore maintain this important placing and continue to build on these achievements and international visibility.

Pablo Vera-Villarroel

Director, Terapia Psicológica

Caterina Manzo, Jaime Silva and Walter Kühne

Associate Directors 